\title{
Correction to: Pattern recognition and pharmacokinetic methods on DCE-MRI data for tumor hypoxia mapping in sarcoma
}

\author{
M. Venianaki ${ }^{1,2} \cdot$ O. Salvetti ${ }^{3}$ - E. de Bree ${ }^{4}$ - T. Maris ${ }^{5}$. \\ A. Karantanas ${ }^{5}$ - E. Kontopodis ${ }^{2}$ - K. Nikiforaki ${ }^{2}$. \\ K. Marias ${ }^{2}$
}

Published online: 5 January 2018

(C) The Author(s) 2018. This article is an open access publication

\section{Correction to: Multimed Tools Appl (2017) \\ https://doi.org/10.1007/s11042-017-5046-6}

The article Pattern recognition and pharmacokinetic methods on DCE-MRI data for tumor hypoxia mapping in sarcoma, written by M. Venianaki, O. Salvetti, E. de Bree, T. Maris, A. Karantanas, E. Kontopodis, K. Nikiforaki, K. Marias, was originally published

The online version of the original article can be found at https://doi.org/10.1007/s11042-017-5046-6

M. Venianaki

maria.venianaki@imtlucca.it

O. Salvetti

ovidio.salvetti@isti.cnr.it

E. de Bree

debree@uoc.gr

T. Maris

tmaris@med.uoc.gr
A. Karantanas
akarantanas@gmail.com
E. Kontopodis
elko@ics.forth.gr
K. Nikiforaki
kat@ics.forth.gr
K. Marias
kmarias@ics.forth.gr 
electronically on the publisher's internet portal (currently SpringerLink) on August 9, 2017 without open access.

With the author(s)' decision to opt for Open Choice the copyright of the article changed on December 2017 to () The Author(s) 2017 and the article is forthwith distributed under the terms of the Creative Commons Attribution 4.0 International License (http://creativecommons. org/licenses/by/4.0/), which permits use, duplication, adaptation, distribution and reproduction in any medium or format, as long as you give appropriate credit to the original author(s) and the source, provide a link to the Creative Commons license and indicate if changes were made.

The original article has been corrected.

Open Access This article is distributed under the terms of the Creative Commons Attribution 4.0 International License (http://creativecommons.org/licenses/by/4.0/), which permits unrestricted use, distribution, and reproduction in any medium, provided you give appropriate credit to the original author(s) and the source, provide a link to the Creative Commons license, and indicate if changes were made.

1 Image Analysis Research Unit, IMT School for Advanced Studies Lucca, Lucca, Italy

2 Computational Bio-Medicine Laboratory, Institute of Computer Science, Foundation for Research and Technology - Hellas, Heraklion, Greece

3 Istituto di Scienza e Tecnologie dell'Informazione "Alessandro Faedo" CNR, Area della Ricerca CNR di Pisa, Pisa, Italy

4 Department of Surgical Oncology, Medical School of Crete University Hospital, Heraklion, Greece

5 Department of Radiology, Medical School - University of Crete, Heraklion, Greece 